UTILITY: Jurnal IImiah Pendidikan dan Ekonomi

Volume 5, No. 2, Agustus 2021 Page 16-23

ISSN 2549-1377 (Print) || ISSN 2549-1385 (Online)

Available online at http://journal.stkipnurulhuda.ac.id/index.php/utility

\title{
PENGARUH MODEL PEMBELAJARAN KOOPERATIF TIPE STUDENT TEAMS ACHIVMENT DIVISION (STAD) TERHADAP HASIL BELAJAR IPS SISWA KELAS VIII DI SMP NEGERI 1 BELITANG MADANG RAYA
}

\author{
Hengki Setiawan ${ }^{1}$, Hj. Rusmiati, S.E., M.Si. ${ }^{2}$, Khafid Ismail, M.Pd ${ }^{3}$ \\ ${ }^{1,23}$ STKIP Nurul Huda \\ *E-mail: stwnhngki@gmail.com
}

\begin{abstract}
Abstrak: Salah satu tolak ukur keberhasilan guru adalah dalam pembelajaran mencapai hasil yang optimal, salah satu model pembelajaran yang sesuai adalah koopertaif tipe student teams achivment division (STAD) adalah model pembelajaran dalam bentuk kelompok yang memiliki latar belakang kelompok heterogen yang menekankan aktivitas belajar pada siswa agar siswa dapat memiliki komponen presentasi kelas dan bekerjasama dengan antar teman. Penelitian ini bertujuan untuk mengetahui Pengaruh model pembelajaran kooperatif tipe student teams achivment division (STAD) Terhadap Hasil Belajar siswa Kelas VIII Di SMP Negeri 1 Belitang Madang Raya. Penelitianinimerupakanpenelitiandeskriptifkuantitatif, hasil dari analisis pengolahan data penelitian ada pengaruh positif dan signifikan yakni berdasarkan pengujian hipotesis, didapat bahwa nilai $t_{\text {hitung }}$ yang lebih besar darit tabel , yaitu $78,22>80,74$. Hal tersebut membutikan model pembelajaran kooperatif tipe student teams achivment division (STAD) berengaruh terhadap hasil belajar.
\end{abstract}

Kata Kunci: Student Teams Achivment Division (STAD) Dan Hasil Belajar.

\section{PENDAHULUAN}

Praktek pendidikan saat ini selain ditandai oleh peran guru yang dominan juga ditandai dengan siswa yang hanya menghafal materi pelajaran. Hal ini sering terjadi pada proses pembelajaran materi ilmu pengetahuan sosial (IPS). Siswa masih menganggap hanya dengan menghafal mereka dapat menguasai suatu konsep untuk mendapat hasil belajar yang maksimal. Sedangkan menurut Nugroho (2014: 35), ilmu pengetahuan sosial (IPS) merupakan salah satu mata pelajaran yang dirancang dan dilaksanakan untuuk mengembangkan karakteristik siswa dalam cara berfikir, 


\section{Pengaruh Model Pembelajaran Kooperatif Tipe Student Teams Achivment Division (Stad) Terhadap Hasil Belajar IPS Siswa Kelas VIII Di Smp Negeri 1 Belitang Madang Raya}

bersikap, dan berperilaku sosial untuk hidup bermasyarakat menjadi warga Negara Indonesia yang baik.

Menurut Suprijono (2012:61), model pembelajaran kooperatif dikembangkan untuk mencapai keaktifan dan hasil belajar berupa prestasi akademik, toleransi, menerima keragaman, dan pengembangan keterampilan sosial". Salah satu masalah yang dihadapi di SMP Negeri 01 Belitang Madang Rayaadalah hasil belajar siswa yang belum memenuhi standar ketuntasan belajar, hal ini dikarenakan kurang aktifnya siswa dalam belajar khususnya pada mata pelajaran IPS. Untuk memperbaik hal tesebut perlu diterapkan suatu model pembelajaran kooperatif tipe students Teams-Achivment Division (STAD). Karena model pembelajaran STAD siswa dibagi menjadi beberapa kelompok untuk membahas materi, kemudian siswa yang telah memahami materi diwajibkan mengajarkan kepada kelompoknya (Suparsawan, 2020).

Berdasarkan penjelasan di atas penulis akan meneliti lebih lanjut mengenai model pembelajaran STAD dalam meningkatkan hasil belajar siswa, dengan judul :"Pengaruh Metode Student Teams Achivment Division ( STAD) Kelas VIII Di SMP Negeri 01 Belitang Madang Raya".

\section{METODE}

Penelitian ini menggunakan jenis penelitian deskriptif kuantitatif, yaitu untuk menggambarkan dan menafsirkan data mengenai pemanfaatan sumber belajar terhadap hasil belajar IPS siswa kelas VIII di SMP Negeri 1 Belitang Madang Raya dan data-data yang diperoleh berupa angka-angka lalu dalam pengelohan datanya menggunakan metode statistik. Penelitian ini memiliki dua variabel yaitu variabel bebas atau variabel independen dan variabel terikat atau variabel dependen. Variabel independen pada penelitian ini adalah pengaruh pemanfaatan sumber belajar, sedangkan variabel dependen pada penelitian ini adalah hasil belajar IPS siswa kelas VIII di SMP Negeri 1 Belitang Madang Raya

Populasi penelitian ini adalah seluruh siswa kelas VIII di SMP Negeri 1 Belitang Madang Rayatahun Pelajaran 2020/2021 yang berjumlah 251siswa yang terbagi dalam 8 kelas. Sampel penelitian ini adalah peserta didik kelas VIII ${ }^{1}$ dan VIII 
yang berjumlah 63 siswa. Teknik pengumpulan data yang digunakan adalah angket dan dokumentasi. Uji instrumen yang dilakukan adalah uji validitas dan uji reliabilitas.Teknik analisis data yang digunakan adalah uji deskriptif, uji normalitas, uji linearitas, analisis regresi linear sederhan dan uji hipotesis.

\section{HASIL DAN PEMBAHASAN}

\section{Hasil}

Table 1

Tests of Normality

One-Sample Kolmogorov-Smirnov Test

\begin{tabular}{|c|c|c|}
\hline & & $\begin{array}{c}\text { Unstandardized } \\
\text { Residual }\end{array}$ \\
\hline \multicolumn{2}{|l|}{$\mathrm{N}$} & 25 \\
\hline \multirow[t]{2}{*}{ Normal Parameters ${ }^{a}$} & Mean & .0000000 \\
\hline & Std. Deviation & 2.89663459 \\
\hline \multirow[t]{3}{*}{ Most Extreme Differences } & Absolute & .247 \\
\hline & Positive & .247 \\
\hline & Negative & -.128 \\
\hline \multicolumn{2}{|l|}{ Kolmogorov-Smirnov Z } & 1.236 \\
\hline \multicolumn{2}{|l|}{ Asymp. Sig. (2-tailed) } & .094 \\
\hline \multicolumn{2}{|l|}{ a. Test distribution is Normal. } & \\
\hline
\end{tabular}

Berdasarkan tabel diatas nilai sig kedua variabel lebih besar dari nilai sig yang telah ditetapkan $(0,05)$. Yaitu pengaruh model pembelajaran kooperatif tipe Student eans Achivment Division (STAD) terhadap hasil belajar pada kelas eksperimen 0,094<0,005 maka dapat disimpulkan bahwa sampel yang digunakan berdistribusi normal. Penyebaran titik disepanjang garis slope pada tabel. 1 di atas maka menunjukkan data tersebut berdistribusi normal.

\section{Uji Homogenitas}

Uji homogenitas digunakan untuk mengetahui sama tidaknya variansi-variansi dua buah distribusi atau lebih. Uji homogenitas yang akan dibahas dalam tulisan ini adalah Uji Homogenitas Test of Homogenity of Variances dilakukan untuk mengetahui apakah data dalam variabel $X$ dan $Y$ bersifat homogen atau tidak. Dapat dilihat pada tabel 2. 


\section{Pengaruh Model Pembelajaran Kooperatif Tipe Student Teams Achivment Division (Stad) Terhadap Hasil Belajar IPS Siswa Kelas VIII Di Smp Negeri 1 Belitang Madang Raya}

Tabel. 2

Test of Homogeneity of Variances

Test of Homogeneity of Variance

\begin{tabular}{|ll|l|c|c|c|}
\hline & & $\begin{array}{l}\text { Levene } \\
\text { Statistic }\end{array}$ & $\mathrm{df1}$ & $\mathrm{df2}$ & Sig. \\
\hline Hasil & Based on Mean & .232 & 1 & 48 & .632 \\
Belajar & Based on Median & .016 & 1 & 48 & .900 \\
& $\begin{array}{l}\text { Based on Median and with } \\
\text { adjusted df } \\
\text { Based on trimmed mean }\end{array}$ & .016 & 1 & 39.966 & .900 \\
& & & & \\
&
\end{tabular}

Sumber: Lampiran 6 output SPSS 16

Berdasarkan tabel. 2 di atas berdasarkan Based on Median and with adjusted df memiliki taraf signifikan 0,700 sedangkan taraf signifikan 0,05. karena taraf signifikan pada uji homogenitas sebesar $0,700>0,05$ maka data tersebut bersifat homogen.

\section{Uji Regresi Linier Sederhana}

Pengujian ini dilakukan untuk mengetahui pengaruh terhadap masing-masing variabel bebas, untuk megetahui hasil pengaruh signifikan secara bersama-sama terhadap hasil belajar siswa. Pengambilan keputusan dalam uji regresi linier sederhana dapat mengacu pada dua hal yaitu:

Membandingkan nilai signifikansi dari nilai probalitas 0.05

- Jika nilai signifikansi $<0.05$, artinya variabel berpengaruh terhasdap variabel y

- Jika nilai signifikansi $>0.05$, artinya variabel tidak berpengaruh terhasdap varriabel y

Tabel. 3

ANOVA $^{\mathrm{b}}$

Uji Regresi liner sederhana

\begin{tabular}{|l|l|l|l|l|l|}
\hline Model & Sum of Squares & df & Mean Square & F & Sig. \\
\hline 1 Regression & 22.868 & 1 & 22.868 & 2.612 & $.120^{\mathrm{a}}$ \\
\hline
\end{tabular}




\begin{tabular}{|l|l|l|l|l|l|} 
Residual & 201.372 & 23 & 8.755 & & \\
Total & 224.240 & 24 & & & \\
\hline
\end{tabular}

a. Predictors: (Constant), Religiusitas

b. Dependent Variable: Agresivitas

Dari output tersebut dapat diketahui bahwa nilai $\mathrm{F}$ hitung $=2.612$ dengan tingkat signifikansi sebesar $0.120<0.05$, maka model regresi tidak dapat dipakai untuk memprediksi variabel Religiusitas $(\mathrm{X})$ terhadap variabel Agresivitas $(\mathrm{Y})$.

Tabel.4

Model Summary

\begin{tabular}{|l|l|l|l|l|}
\hline Model & $R$ & $R$ Square & $\begin{array}{l}\text { Adjusted } \\
\text { Square }\end{array}$ & $\begin{array}{l}\text { Std. Error of } \\
\text { the Estimate }\end{array}$ \\
\hline 1 & $.319^{\mathrm{a}}$ & .102 & .063 & 2.959 \\
\hline
\end{tabular}

a. Predictors: (Constant), Religiusitas

Tabel diatas menjelaskan besarnya nilai korelasi/hubunan $(R)$ yaitu sebesar 0,319 dari output tersebut diperoleh koefisien determinasi ( $R$ Square) sebesar 0,102 yang mengandung pengertian bahwa pengaruh variabel bebas (religiusitas) terhadap variabel terikat (agresivitas) adalah sebesar 10,2\%.

\section{Uji Hipotesis}

Uji parsialdigunakan untuk mengetahui pengaruh variabel independenterhadap variabel dependen secara individu atau (persial). Rumus yang digunakan menurut (Mustofa, 2014:64) sebagai berikut:

$$
\begin{aligned}
& t_{i}=b_{i} / S E b_{i} \\
& \text { Keterangan: } \\
& \text { - } t_{i}=\text { t hitung } \bullet b_{i}=\text { Koefisien regresi }
\end{aligned}
$$$$
\text { - SE = Standar eror regresi }
$$ 


\section{Pengaruh Model Pembelajaran Kooperatif Tipe Student Teams Achivment Division (Stad) Terhadap Hasil Belajar IPS Siswa Kelas VIII Di Smp Negeri 1 Belitang Madang Raya}

Jika $\mathrm{t}$ hitung $\geq \mathrm{t}$ tabel pada taraf signifikansi 0,05 maka terdapat pengaruh yang signifikan antara variable bebas terhadap variable terikat secara individu dan hipotesis diterima, namun jika $\mathrm{t}$ hitung $<\mathrm{t}$ tabel maka tidak terdapat pengaruh yang signifikan antar variable bebas terhadap variable terikat.

Tabel. 5

Coefficients

\section{One-Sample Test}

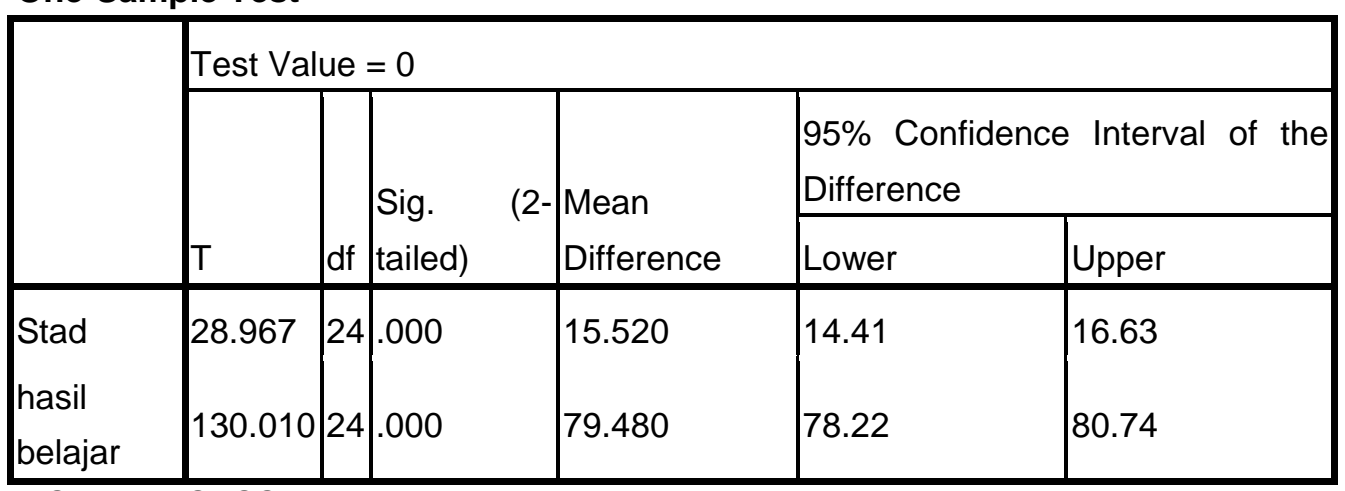

Sumber: SPSS V16

Berdasarkan tabel. 5 menunjukan bahwa Taraf signifikan $5 \%(0,05)$, dan hasil T hitung78,22 ; sig=80,74 maka dapat ditarik kesimpulan HO diterima yang artinya tedapat pengaruh metode pembelajaran kooperatif Tipe Student Teams Achivment Division terhadap hasil belajar peserta didik pada mata pelajaran ekonomikelas VIII di SMP Negeri 1 Belitang Madang Raya.

\section{Pembahasan}

Berdasarkan model persamaan regresi yang diperoleh dengan koefisien konstanta dan koefisien variabel yang ada dikolom Unstandardized Coefficients B.diperoleh model persamaan regresi $Y=90,130-0,331=89,799$. Jadi model pembelajaran kooperatif tipeStudent Teams Achivment Division (STAD dalam penelitian ini memiliki pengaruh sebesar 89,799 sedangkan sisanya sebesar 10,201 dipengaruhi olehfaktor lainnya. 


\section{SIMPULAN}

Pertama, secara keseluruhan perbedaan hasil belajar IPS siswa lebih baik yang di ajarkan dengan model STAD daripada dengan metode ceramah. pelaksanaan pembelajaran model STAD mempunyai dampak yang positif terhadap hasil belajar siswa. Kedua, terdapat pengaruh interaksi antara model pembelajaran dan keaktifan siswa yang mempengaruhi hasil belajar IPS siswa kelas VIII. ketiga, perbedaan hasil belajar siswa yang memiliki kurang aktifnya siswa di kelas dapat menggunakan model pembelajran kooperatif tipe STAD ini dripada metode ceramah.

\section{UCAPAN TERIMAKASIH}

Ucapan terimakasih ditujukan kepada STKIP Nurul Huda Sukaraja yang menjadi bagian perjalanan menempuh pendidikan Sarjana Pendidikan Ekonomi dan juga kepada seluruh pihak yang telah ikut serta dalam pembuatan artikel penulis. Kepada kedua orang tua dan kedua pembimbing penulis, serta teman-teman seperjuangan yang telh menorehkan banyak cerita dan juga pengalaman.

\section{REFERENSI}

Rifai, M., \& Hardjono, N. (2019). Meta-analisis keefektifan model pembelajaran student team achievement division (STAD) dalam meningkatkan hasil belajar IPS siswa SD. Primary: Jurnal Pendidikan Guru Sekolah Dasar, 8(2), 174181.

Suprijono, Agus. (2012). Cooperative Learning: Teori Dan Aplikasi PAIKEM. Yogyakarta: Pustaka Pelajar.

Suparsawan, I. K., \& SD, S. P. (2020). Kolaborasi Pendekatan Saintifik dengan Model Pembelajaran STAD Geliatkan Peserta Didik. TATA AKBAR.

Arikunto.(2013). Prosedur Penelitian. Jakarta. Rinika Cipta.

Aulia Rosyidah.(2011). Penerapan Model Pembelajaran Kooperatif Tipe STAD

(Student Teams Achivment Division) Dengan Tutor Sebaya Untuk Meningkatkan Hasil Belajar Siswa Kelas VIII Di SMP Negeri 14 Semarang.

Ni Wayan Widi Astuti.(2017). Pengaruh penerapan Model Pembelajaran Kooperatif Tipe STAD Terhadap Peningkatan Prestasi Belajar Mata Pelajaran IPS Pada Siswa Kelas VIII SMP N 1 Sukawati. 


\section{Pengaruh Model Pembelajaran Kooperatif Tipe Student Teams Achivment Division (Stad) Terhadap Hasil Belajar IPS Siswa Kelas VIII Di Smp Negeri 1 Belitang Madang Raya}

Noor Anifah.(2014). Pengaruh model pembelajaran student teams achivment division (STAD) dan konvensional terhadap prestasi belajar siswa ditinjau dari minat belajar pada mata pelajaran IPS kelas VIII Mts Negeri Di Kabupaten Kudus.

Nurhayati Poloung.(2017). Pengaruh Model Pembelajaran Kooperatif Tipe STAD Terhadap Motivasi Belajar Dan Hasil Belajar IPS Di SMP Negeri 1 Anggrek Kabupaten Gorontalo Utara.

Saripudin.(1989). Konsep Dan Masalah Pengajaran IImu Sosial Di Sekolah Menengah. Jakarta: Depdiknas.

Sugiyono.(2010). Statistik Untuk Penelitian. Bandung: Alfabeta Bandung.

Wibowo. (2016). Penerapan Model Kooperatif Tipe STAD Dalam Peningkatan Pembelajaran Bangun Datar Pada Siswa Kelas V SD. Kalam Cendekia PGSD Kebumen. 